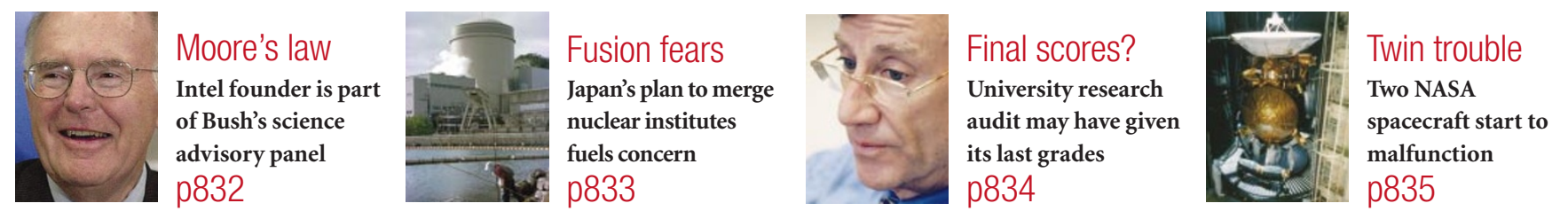

\title{
Map data kept under wraps as Pentagon focuses on security
}

Jonathan Knight, San Francisco

Geophysicists keen to access the most comprehensive topographical maps of the Earth ever produced are facing a longer wait than expected. The US Department of Defense has delayed the release of the maps, citing unspecified security concerns.

The maps are currently being assembled from data collected by the Shuttle Radar Topography Mission (SRTM). This joint project between the defence department and NASA - with additional contributions from the German Aerospace Center and the Italian Space Agency - aims to provide high-resolution maps of $80 \%$ of the Earth's land surface by the end of 2002 .

One part of the project is mapping changes in elevation of as little as 8 metres for each continent. The first of these maps, covering North America, is scheduled to be finished in spring 2002. Another part of the effort is focusing on sites of scientific interest and is generating maps of 'cells' covering one degree longitude by one degree latitude. So far, 138 such cells

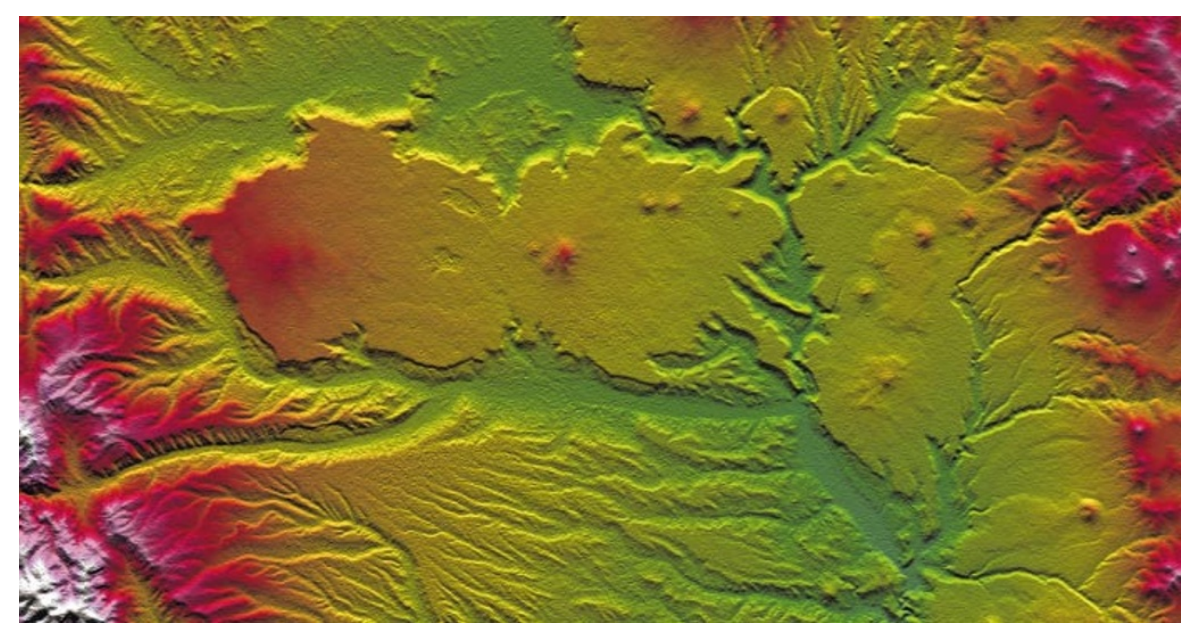

Clampdown: low-resolution images, such as this of Argentina, are available from the SRTM project.

have been created, and these were expected to be released as soon as they were finished.

But after the 11 September terrorist attacks, the Pentagon's National Imagery and Mapping Agency (NIMA), which co-

\section{Spain sets sights on fusion facility}

Sally Goodman

Spain is considering a late bid to host the proposed ITER international fusion research facility.

The Madrid-based Research Centre for Energy, Environment and Technology (CIEMAT) is carrying out a feasibility study into the prospect of a Spanish site for ITER. If a suitable site is identified and backed by the government, Spain would compete with France, Canada and Japan to host the facility.

"We see this as an important opportunity to develop high technology in Spain," says Felix Yndurain, CIEMAT's director general, "but we haven't yet discussed where the money will come from.” He adds that Spain will decide in about three months whether to pursue the idea further.

At the beginning of 2002, Spain will assume the presidency of the European Union
— a platform that is often used by member states to launch grandiose initiatives. Spain may decide that an offer to host ITER would appropriately signal its growing scientific and technical aspirations. But critics point out that the country has no special expertise in the technology of magnetic fusion that will be used by ITER.

The United States' withdrawal from ITER in 1998, as well as the doubts of the other partners - Japan, Russia and the European Union - about the likely cost of the original ITER design proposal, have caused the project to be slowed and scaled back. The partners say that they are negotiating a legal framework for it, but will not choose a site until the end of next year at the earliest. Their choice will rest largely on which — if any - bid can muster the political support that will be needed to complete the project. sponsors the project, placed a moratorium on any new releases of data pending a review of their implications for national security.

Officials at the agency will not say what the security implications of releasing the data might be. But accurate topographical data have various obvious military uses. They are indispensable, for example, for the navigation of low-flying, high-speed aircraft and of cruise missiles.

On 5 December, NIMA cleared the release of SRTM cell maps of the United States and its territories on the grounds that similar data are already in the public domain. These new maps are now available and join the handful of cell images of an area in Colorado that had been released before 11 September.

Data for the project were collected during a space-shuttle flight in February 2000. The Earth's surface between the latitudes 60 degrees north and 56 degrees south were scanned and, by comparing radar images taken from each end of a 60-metre boom, the SRTM's interferometer measured points of elevation on the Earth's surface. The measurements were originally expected to be within 16 metres, but researchers estimate that the instrument achieved twice that precision.

The bulk of the data are being processed by NASA's Jet Propulsion Laboratory in Pasadena, California, where a team is assembling a global map from the 12 terabytes 
of information gathered.

At the annual meeting of the American Geophysical Union in San Francisco earlier this month, scientists who had applied more than a year ago for access to the emerging maps were forced to cancel a presentation that would have been based on information from the images.

"We had hoped that the restriction would be lifted in time for the meeting," says Peter Mouginis-Mark, a volcanologist at the University of Hawaii in Honolulu who wants to use the cell maps to study the geological effects of the 1991 eruption of Mount Pinatubo.

Although most of the Earth has been mapped in detail from space, the elevation information for many areas is incomplete. Mouginis-Mark and several other scientists who presented their SRTM plans at the meeting are still waiting for the non-US maps. "The whole community is very anxious to get them," says Mouginis-Mark.

John LaBrecque, the NASA liaison with the Pentagon on the SRTM, says he has no idea when NIMA will release the non-US maps. "It is still under review," he says.

Even when the maps do enter the public domain, NIMA's original agreement with NASA allows the military to keep the most accurate versions for itself. For territories outside the United States, the public maps will have a resolution only one-third as precise as those held by the US military.

- www.jpl.nasa.gov/srtm

\section{Bush turns to Silicon Valley moguls for scientific advice}

\section{Tony Reichhardt, Washington}

The new President's Council of Advisors on Science and Technology (PCAST) — named by the White House last week — is dominated by computer-industry executives.

Bench scientists are thinly represented on the 24-strong panel, whose job it is to guide the White House on science and technology matters, but whose influence has varied between administrations.

Among the new PCAST members are two legendary figures from the informationtechnology industry: Michael Dell, chairman of Dell, and Gordon Moore, chairman emeritus of Intel. Robert Herbold, a vice-president at Microsoft, Carol Bartz, chief executive of software supplier Autodesk, and George Scalise, president of the Semiconductor Industry Association, are also on the panel.

In addition, President Bush has tapped some old hands from previous Republican administrations including Walter Massey and Bernadine Healy, who headed the National Science Foundation (NSF) and the National Institutes of Health, respectively, under his father. Another former NSF director, Erich Bloch, will be on the council, as will two holdovers from President Clinton's PCAST Charles Vest, president of the Massachusetts
Institute of Technology, and retired aerospace executive Norman Augustine.

Newcomers on the panel include Charles Arntzen, a biotechnologist at Arizona State University, and Kathleen Behrens, a biotechnology analyst with investment-management firm Robertson Stephens. University administrators asked to join include Wayne Clough, president of the Georgia Institute of Technology, and Marye Anne Fox, chancellor of North Carolina State University.

PCAST will be co-chaired by White House science adviser John Marburger and Floyd Kvamme, a Silicon Valley venture capitalist.

Bush met with the group immediately after its first meeting on 12 December, which optimists take as an encouraging sign of his interest in the panel. White House officials say that PCAST will concentrate its early efforts in four areas: energy efficiency, information technology, counter-terrorism, and an overall assessment of federal research funding. They add that the heavy representation of information technology on the panel reflects its importance to the economy and to science.

According to a source familiar with Bush's plans for PCAST, the panel will concentrate on preparing memos to the president, rather than public reports.

\section{Canadian budget cranks up investment in research}

\section{David Spurgeon, Montreal}

The Canadian government has unveiled plans to spend Can\$7.4 billion (US\$4.7 billion) next year on science and technology, an increase of $8 \%$ over the previous year.

The announcement, which continues a major revival of Canadian research spending that has been under way since 1998 , was made on 10 December as part of an overall budget that emphasizes large increases in military spending and counter-intelligence.

The budget includes an extra Can $\$ 36.5$ million for the Natural Sciences and Engineering Research Council (NSERC), which funds university research in engineering and the physical sciences, taking its budget to Can $\$ 560$ million. The National Research Council (NRC), which runs most of the federal government's research laboratories, gets a Can\$40-million increase, giving it a budget of Can $\$ 536$ million. The Canadian Institutes of Health Research will see an increase of Can $\$ 75$ million, lifting its budget to about Can $\$ 560$ million.

The NRC has been allocated Can $\$ 110$ million over three years to support recent high-technology ventures such as a planned national institute for nanotechnology. The government will also provide a one-off payment of Can\$200 million to help universities to meet research overhead costs, and a further Can\$110 million to build a new, high-capacity broadband network to link research institutions and universities.

"Given the circumstances, I think it's quite a balanced approach," says John de la Mothe, a science-policy expert at the University of Ottawa. "Overall, it's good for the universities and very positive for the research community."

Bob Wolkow, a physicist at the NRC's Steacie Institute of Molecular Science in Ottawa, says he is "pretty pleased" with the budget. He adds that, given the government's fiscal difficulties, it is "all the more remarkable that we have got pretty substantial new funding".

But David Schindler, an ecologist at the University of Alberta who recently won the Herzberg medal for academic excellence from the NSERC, argues that the government should worry less about

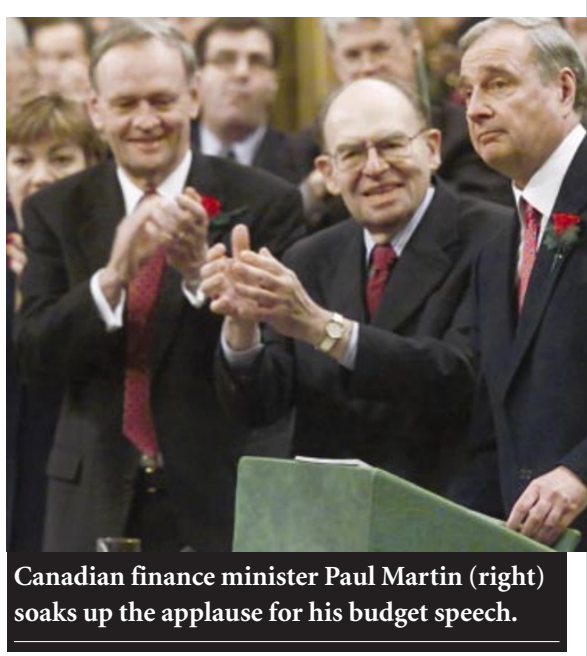

international terrorism and more about pollution at home. "It just looks to me like they've got their priorities backwards," he says. Schindler adds that Canada's politicians do not seem to care about environmental damage, despite the fact that seven deaths have occurred from Escherichia coli contamination in Ontario in the past year. 